Zabytkoznawstwo i Konserwatorstwo XLI, Toruń 2011

Barbara Maria Gawęcka

\title{
Dzieje budynku Collegium Maius Uniwersytetu Mikołaja Kopernika w Toruniu
}

Tiniejszy artykuł stanowi część dokumentacji historycznej sali 1 im. Ludwika Kolankowskiego Collegium Maius Uniwersytetu Mikołaja Kopernika w Toruniu. Konserwacja i restauracja powyższego obiektu prowadzona była przez zespół konserwatorów, pod kierunkiem prof. Bogumiły Rouba w 2008 roku ${ }^{1}$. Autorka została poproszona o wykonanie kwerendy archiwalnej, która miała pomóc w interpretacji odkrytych malowideł. Współpraca z konserwatorami oraz twórcze dyskusje prowadzone podczas prac nadawały kierunek poszukiwaniom archiwalny ${ }^{2}$, które zaowocowały spisaną poniżej historią budynku.

Likwidacja części średniowiecznych murów i fosy, które utraciły swoją pierwotną funkcję obronną, zwolniła tereny pod budowę wielu gmachów publicznych, takich jak: remiza straży pożarnej, teatr miejski, siedziba banku przy placu Rapackiego ${ }^{3}$. Jedną z inwestycji prowa-

1 Dokumentacja prac konserwatorskich i restauratorskich. Malowidła ścien$n e$ w auli im. Ludwika Kolankowskiego w Collegium Maius Uniwersytetu Mikołaja Kopernika $w$ Toruniu (XX w.). Autor prac konserwatorskich i restauratorskich: zespół artystów konserwatorów dzieł sztuki, pod kierunkiem: prof. zw. dr kwal. II st. Bogumiły Rouba, mgr Jolanty Korcz, mgr Solidy Lim, autor dokumentacji - mgr Ludmiła Tymińska-Widmer, autorzy badań specjalistycznych: badania historyczne - mgr Barbara Maria Gawęcka, badania budowy technicznej - mikrofotografie przekrojów próbek w świetle VIS i UV - dr Zuzanna Rozłucka, Toruń 2008.

2 Pragnę także podziękować za pomoc i cenne wskazówki podczas pisania dokumentacji historycznej prof. dr. hab. Zygmuntowi Kruszelnickiemu.

3 K. Wajda, Pod ponownym pruskim panowaniem (1815-1920), w: Toruń dawny i dzisiejszy. Zarys dziejów, pod red. M. Biskupa, Warszawa-Poznań-Toruń 1983, s. 357; B. Rymaszewski, Założenia konserwatorskie i przyszłość toruńskiej dzielnicy staromiejskiej, „Rocznik Toruński” 1966, t. I, s. 141; R. Sudziński, Toruń. Portret miasta, Warszawa 1988, s. 24. 
dzonych na tym terenie w początkach XX wieku była budowa Szkoły Przemysłowej $^{4}$ (obecnego Collegium Maius). Budynek miał zająć narożną działkę pomiędzy ulicami Wały gen. Sikorskiego a Fosa Staromiejska ${ }^{5}$. Na podstawie odpisu dokumentu z 6 września 1901 roku, sporządzonego 15 maja 1920 roku dla Wojewody Pomorskiego, dowiadujemy się, że między „Przewodniczącym Okręgu Regencyjnego w Kwidzyniu w roli Przedstawiciela Pruskiego Fiskusa Królewskiego i Magistratem Torunia w roli Przedstawicieli Miasta Torunia zostaje zawarta następująca umowa z zastrzeżeniem zatwierdzenia jej przez Pana Ministra ds. Handlu i Rzemiosła: $₫ 1$. Miasto Toruń wybuduje na bezpłatnie udostępnionym przez siebie placu specjalny budynek dla Zawodowej Szkoły Dokształcającej według wytycznych Pana Ministra ds. Handlu i Rzemiosła oraz według zatwierdzonego przez Pana Ministra projektu. Miasto wyposaży budynek, po wcześniejszej akceptacji Pana Ministra w niezbędny „inwentarz" (sprzęt) oraz potrzebne pomoce naukowe i przybory szkolne"6.

Pierwsza koncepcja budynku autorstwa radcy budowlanego G. Colley'a ${ }^{7}$ powstała już w 1902 roku' $^{8}$. W odpisie Komentarza do projektu budynku Szkoły Dokształcającej w Toruniu, z 6 czerwca 1902 roku, sporządzonego przez Colley’a, czytamy, iż „plac budowy to wybrany przez Przedstawicieli Rządu Krajowego oraz Pana Ministra trójkątny obszar na północ od Sądu Okręgowego. Zostanie on ograniczony ulicami: Fosą [Staromiejską], przedłużoną ulicą Klasztorną i projektowaną

4 M. Wojciechowski, Toruń w latach I wojny światowej 1914-1918, „Rocznik Toruński” 1967, t. II, s. 132.

5 A. Prokop, „Ocena stanu zachowania i stopień zniszczenia biologicznego książek z okresu 1801-1914 z Biblioteki Wydziału Filologicznego Collegium Maius UMK w Toruniu", praca magisterska napisana pod kierunkiem prof. dr hab. A. Strzelczyk, Zakład Konserwacji Papieru i Skóry, Toruń 2006, s. 13.

6 Archiwum Państwowe w Toruniu, Akta miasta Torunia - budowlane, G 714, karta 280 (tłumaczenie z jęz. niem.).

7 S. Łoza pisze: „Colley. Miejski radca budownictwa w Toruniu. W 1907 r. budował szkołę rzemiosł”. Idem, Architekci i budowniczowie w Polsce, Warszawa 1954, s. 50 .

8 Karta ewidencyjna zabytków architektury i budownictwa, nr 1820, tekst, plany, rysunki i zdjęcia opracowała dr J. Kucharzewska, Archiwum Wojewódzkiego Konserwatora Zabytków w Toruniu; J. Kucharzewska, Architektura i urbanistyka Torunia w latach 1871-1920, Warszawa 2004, s. 285. 
nową ulicą przecinającą dwie powyższe"9. Projekt zakładał dwuetapowość przedsięwzięcia. W pierwszej kolejności przewidywano wybudowanie masywu wzdłuż ul. Wały gen. Sikorskiego, a następnie skrzydła wschodniego od strony dzisiejszej ul. W. Horzycy ${ }^{10}$. Colley, w wyżej cytowanym piśmie, dodaje: „do dalszej rozbudowy zostało zaprojektowane skrzydło boczne, które będzie ustawione przy ulicy przecinającej i przedłużonej ulicy Klasztornej. W skrzydle tym będzie 13 klas i 2 pokoje: dla nauczycieli i na pomoce naukowe, klatka schodowa; w piwnicy powinny znajdować się pomieszczenia kuchenne szkoły prowadzenia gospodarstwa domowego. W przypadku konieczności dobudowy kolejnych pomieszczeń do nauki, można wykorzystać na ten cel miejsce na dziedzińcu. Założono, że wybudowana w pierwszym rzędzie część gmachu będzie udostępniona szkole dokształcającej w godzinach wieczornych, zaś za dnia szkole zawodowej. Dobudowane skrzydło boczne będzie służyło szkole dla dziewcząt i szkole prowadzenia gospodarstwa domowego"11. Tego samego roku Rada Rządu i Rzemiosła ds. Szkolnictwa przedstawiła ocenę projektu budynku szkoły dokształcającej dla miasta Torunia ${ }^{12}$.

Projekty z listopada 1903 roku pokazywały zintegrowane dwie części obiektu połączone korytarzami ${ }^{13}$. W 1903 roku wydano pozwolenie na budowę ${ }^{14}$. Zatwierdzenia projektu dokonał w lutym 1904 roku w Kwidzyniu Regencyjny Radca Budowlany Heinrich von Blase, a prace murarskie rozpoczęto w 1905 roku $^{15}$. Dnia 16 sierpnia 1905 roku w ratuszu odbyły się obrady dotyczące funkcjonowania szkoły. Ze sprawozdania $z$ tego spotkania dowiadujemy się, że „przed rozpoczęciem obrad miało miejsce szczegółowe zwiedzanie prawie ukończonego nowego budynku Zawodowej Szkoły Dokształcającej, która wliczając wyposażenie i od-

9 APT, AmT, G 710, K. 76 rewers (tłumaczenie z jęz. niem.).

10 J.Kucharzewska, Architekturaiurbanistyka Toruniawlatach 1871-1920, s.287.

11 APT, AmT, G 710, K. 77 (tłumaczenie z jęz. niem.).

12 Odpis pisma z 2 lipca 1902 r., Ocena projektu budynku szkoły dokształcającej dla miasta Torunia wystawiona w Miejskim Urzędzie ds. Budownictwa 6 czerwca 1902 r., APT, AmT, G 710, K. 78-79.

13 J. Kucharzewska, Architektura i urbanistyka Torunia w latach 1871-1920, s. 287.

14 APT, AmT, G 711, K. 199.

15 J. Kucharzewska, Architektura i urbanistyka Torunia w latach 1871-1920, s. 287. 
setki z pieniędzy na budowę będzie kosztowała pełne 800000 Marek"16. Ustalono także, że w nowym budynku zostaną umieszczone trzy szkoły: szkoła budowlana, koedukacyjna szkoła handlowa dla młodzieży oraz szkoła dla dziewcząt o profilu "prowadzenie gospodarstwa domowego"17.

Technologię wykonania masywnych stropów piwnic opracowała firma Acermann, cegłę dostarczała cegielnia Meissner \& Wünst Graudenz Damphziegelei, granit Karl Dehmel z Girlachsdorfu (Gilow koło Dzierżoniowa), a beton Actien-Gesellschaft für Beton und Monierbau z Berlina ${ }^{18}$. Zachowała się korespondencja z ActienGesellschaft für Beton und Monierbau ${ }^{19}$, z której można się dowiedzieć, że wyżej wymienione przedsiębiorstwo odpierało zarzuty, iż powinno ponosić koszty za ponowne malowanie sufitów i usunięcie powstałych rys. Twierdzono, iż rysy nie były efektem złego przygotowania materiałów tylko terenu, na którym postawiono budynek i jego "pracy” ${ }^{20}$. Przy pracach budowlanych i wykończeniowych brały udział także firmy: Gebrüder Pichert GmbH - firma zajmująca się handlem materiałami budowlanymi, Houtermans \& Walter - właściciele tartaku oraz składu drewna i innych materiałów budowlanych ${ }^{21}$, P. Trautmann - tapicer i dekorator-sztukator, firma z siedzibą przy Rynku Nowomiejskim 17 w Toruniu ${ }^{22}$, P. Borkowski - stolarz, Karl Schall - kierownik magazynu meblarskiego itd. Budynek był wyposażony w wentylację mechaniczną oraz w centralne ogrzewanie ${ }^{23}$. Grzejniki dostarczała firma Emil Kelling z Berlina, zajmująca się instalacją urządzeń grzewczych i wyciągów ${ }^{24}$. Zachowała się także oferta handlowa z 1912 roku przedsiębiorstwa Carl Flohr Maschinen - Fabrik skierowana do Magistratu, na zakup windy

16 Sprawozdanie z obrad. Toruń 16 sierpnia 1905 r., APT, AmT, G 713, K. 77 (tłumaczenie z jęz. niem.).

17 Ibidem, K. 78 rewers.

18 Karta ewidencyjna zabytków architektury i budownictwa, nr 1820.

19 APT, AmT, G 713, K. 179 rewers; APT, AmT, G 713, K. 161 rewers; APT, AmT, G 713, K. 121.

20 APT, AmT, G 714, K. 71 rewers-74.

21 Karta ewidencyjna zabytków architektury i budownictwa, nr 1820.

22 ibidem; APT, AmT, G 713, K. 227-228.

23 Karta ewidencyjna zabytków architektury i budownictwa, nr 1820.

24 APT, AmT, G 714, K. 134 rewers; APT, AmT, G 714, K. 209 rewers-210; APT, AmT, G 713, K. 255 rewers-256; APT, AmT, G 713, K. 244. 
kuchennej do szkoły ${ }^{25}$. W trakcie prac budowlanych powstawały dodatkowe szczegółowe rysunki detali architektonicznych oraz ogrodzenia, wszystkie sygnowane przez miejskiego radcę budowlanego Brunona Gauera. Był on także autorem większości projektów wyposażenia wnętrz (szaf na przybory naukowe, tablic, regałów na książki, stołów laboratoryjnych, ławek i krzeseł, stojaków na mapy, sztalug i skrzynek na papier itp.), które powstawały sukcesywnie w latach $1905-1907^{26}$.

Budynek został ukończony w latach 1906-1907. Aż do lat 20. XX wieku mieściła się w nim Szkoła Przemysłowa ${ }^{27}$. Na osi drugiego piętra budynku znajdowała się aula, czyli dzisiejsza sala im. L. Kolankowskiego. W początkowym projekcie z 1902 roku miało prowadzić do niej tylko jedno wejście od strony południowej (od korytarza) oraz dwa otwory drzwiowe z pomieszczeń sąsiadujących od wschodu i zachodu.

W projekcie ogrzewania i wentylacji z 1903 roku widoczne są już jednak dwa wejścia od południa. Otwory drzwiowe w ścianach wschodniej i zachodniej są o wiele szersze niż pozostałe. W wyżej cytowanym odpisie pisma Colley'a z 6 czerwca 1902 roku, pt. Komentarz do projektu budynku Szkoły Dokształcającej w Toruniu, czytamy: „trzy duże sale do rysunku powinny być połączone ze sobą za pomocą rozsuwanych drzwi, tak by w razie organizowania wystawy móc uzyskać jedno duże, spójne pomieszczenie [...] Na drugim piętrze sale do rysunku i pokój dla modeli. Duża sala do rysunku w części środkowej gmachu powinna zostać lepiej wyposażona niż pozostałe sale i pełnić funkcję auli"28. Zachowały się do dziś projekty drzwi. Obydwie, umieszczone w ścianie południowej, pary drzwi są dwuskrzydłowe o konstrukcji ramowo-płycinowej. Natomiast dwuskrzydłowe, przesuwane, o konstrukcji

25 APT, AmT, G 714, K. 222; APT, AmT, G 714, K. 224; APT, AmT, G 714, K. 227; APT, AmT, G 714, K. 229; APT, AmT, G 714, K. 230-231.

26 Karta ewidencyjna zabytków architektury $i$ budownictwa, nr 1820; J. Kucharzewska, Architektura i urbanistyka Torunia w latach 1871-1920, s. 287; APT, AmT, G 711, K. 238-273 - wyposażenie wnętrz; APT, AmT - dokumentacja techniczna T 47, K. 58 - projekt okien; APT, AmT, T 47, K. 1 - projekt ogrodzenia; APT, AmT, T 47, K. 1 rewers, 33, 34 - projekt drzwi.

27 Toruń. Miasto i ludzie na dawnej fotografii (do 1939 roku), przygotowali M. Arszyński, T. Zakrzewski, pod red. M. Biskupa, Toruń 1995, s. 175; R. Sudziński, Toruń. Portret miasta, s. 24.

28 APT, AmT, G 710, K. 76, 77 (tłumaczenie z jęz. niem.). 
ramowo-płycinowej z profilowaną listwą przymykową drzwi na ścianie zachodniej mają już wtórne odrzwia. Nie zachowało się także nadproże widoczne na projektach, którego ślady odkryto na ścianie podczas prac konserwatorsko-restauratorskich w 2008 roku.

Północna ściana sali przepruta jest trzema symetrycznie rozmieszczonymi, wysokimi, ostrołukowo zamkniętymi oknami, w oprawie kamiennej. Taki kształt okien posiada w budynku jedynie aula (dzisiejsza sala im. L. Kolankowskiego). Forma okien w ogólnym zarysie nie zmieniła się do dnia dzisiejszego. Jedynie w 1985 roku wprawiono w nie witraże.

$\mathrm{Na}$ podstawie zachowanych dokumentów dowiadujemy się, iż w auli Szkoły Przemysłowej odbywały się próby chóru (w sali stało pianino $)^{29}$ oraz wygłaszano w niej ogólnie dostępne odczyty ${ }^{30}$.

Dnia 28 czerwca 1919 roku Niemcy podpisały traktat wersalski ${ }^{31}$, a decyzje powyższego traktatu przesądziły m.in. o powrocie Torunia do Polski ${ }^{32}$. Organizacją administracji na przyznanych Polsce terenach Pomorza zajął się Podkomisariat Naczelnej Rady Ludowej w Gdańsku. Ustawą z dnia 1 sierpnia 1919 roku powołano do życia Ministerstwo b. Dzielnicy Pruskiej. Mocą tej ustawy z przyznanego Polsce terytorium Pomorza utworzono województwo pomorskie. Pierwszym wojewodą pomorskim z ramienia Ministerstwa b. Dzielnicy Pruskiej został mianowany 17 października 1919 roku dr Stefan Łaszewski ${ }^{33}$. Pomnik jemu poświęcony stoi przy dzisiejszym Collegium Maius. Dnia 25 listopada 1919 roku została podpisana w Berlinie polsko-niemiecka umowa regulująca stronę techniczną przekazania Pomorza Polsce. Ustalała ona także tryb przejmowania przez Polaków poszczególnych miejscowości, urzędów i obiektów za pośrednictwem komisarzy państwowych i szcze-

29 APT, AmT, G 714, K. 128, 128 rewers.

30 APT, AmT, G 714, K. 107.

31 K. Przybyszewski, Pierwsze dni niepodległego Torunia w 1920 r., „Rocznik Toruński” 1980, t. XV, s. 209.

32 M. Wojciechowski, W czasach Drugiej Rzeczypospolitej (1920-1939), w: Toruń dawny i dzisiejszy, s. 417.

33 K. Przybyszewski, Pierwsze dni niepodległego Torunia w 1920 r., s. 209-210; Historia Pomorza, t. I: do roku 1466, część I, pod red. G. Labudy, Poznań 1969, s. 45. 
gółowych ${ }^{34}$. Polscy i niemieccy komisarze podjęli pracę z początkiem stycznia $1920 \mathrm{roku}^{35}$. Z dokumentu z dnia 15 stycznia $1920 \mathrm{roku}^{36}$ dowiadujemy się o rozmowach dotyczących przejęcia budynku szkoły. Wojewoda Pomorski wyraził w piśmie życzenie, aby wyznaczyć na komisarza do spraw przejęcia obiektu Arnolda Rosochowicza ${ }^{37}$. Burmistrz miasta Torunia, który brał udział w rozmowach, był gotowy do przekazania polskiemu rządowi budynku szkoły wraz z wyposażeniem ${ }^{38}$. W Archiwum Państwowym w Bydgoszczy znajduje się odpis kontraktu najmu z 1 maja 1920 roku, w którym można przeczytać, że: „\$1. Gmina miasta Torunia reprezentowana przez swój Magistrat, potwierdza że wynajęła dnia 10. 1. 1920 r. Województwu Pomorskiemu na ręce gieneralnego Zastępcy Wojewody p. Tempskiego Szkołę Przemysłową [...] na lat pięć, a mianowicie od 1 stycznia 1920 r. do 31 grudnia 1924 r." ${ }^{39}$ Dnia 9 marca 1920 roku sporządzono umowę pomiędzy Województwem Pomorskim Wydział IV Robót Publicznych a budowniczym Arnoldem Rosochowiczem, według której: „\$1. Województwo Pomorskie Wydział IV daje Panu A. Rosochowiczowi zlecenie wykonania przeróbki gmachu Województwa podług oferty z dnia 30. 1. 20 Pana A. Rosochowicza [...], \$2. Pan A. Rosochowicz obowiązuje się polecone prace 3 dni po udzieleniu zlecenia rozpocząć i to w porządku mu przez kierownictwo Województwa przepisane i prace tak przyspieszyć, że w przeciągu 4 tygodni po rozpoczęciu będą ukończone"40. Z pisma Rosochowicza skierowanego do Inspekcji Budowlanej dowiadujemy się, że w czasie remontu budynku stawiano dodatkowe ściany ${ }^{41}$. W Zestawieniu kosztów przy

34 M. Wojciechowski, Powrót Torunia do Polski w 1920 r., „Rocznik Toruński” 1971, t. V, s. 24; K. Przybyszewski, Pierwsze dni niepodległego Torunia w 1920 r., s. 211.

35 Ibidem.

36 APT, AmT, G 714, K. 263 (tekst w jęz. niem.).

37 APT, AmT, G 714, K. 261.

38 APT, AmT, G 714, K. 263.

39 Odpis kontraktu najmu z 1 maja 1920 r., Archiwum Państwowe w Bydgoszczy, Urząd Wojewódzki Pomorski w Toruniu, sygn. 23445.

40 Umowa $z$ dnia 9 marca 1920 r. [pomiędzy] Województwem Pomorskim Wydział IV Robót Publ. z jednej strony a Panem Rosochowiczem budowniczem z drugiej strony, APB, UWP w Toruniu, sygn. 23445.

41 Pismo Arnolda Rosochowicza do Inspekcji Budowlanej z dnia 5 maja 1920 r.: Odwołując się na ustna rozmowe $z$ panem Solnem upraszam o odpłatę we wysokości 
przebudówce gmachu szkoły przemysłowej ${ }^{42}$, sporządzonym 18 czerwca 1920 roku wyszczególnione są prace ciesielskie, stolarskie, ślusarskie, a także prace malarskie, w których uwzględniono bielenie ścian, gruntowanie lub pomalowanie albo polakierowanie drzwi.

W dniu 18 stycznia 1920 roku wojsko polskie wkroczyło do Torunia $^{43}$. W artykule Heleny Steinbornowej z dnia 9 lutego 1924 roku, zamieszczonym w „Tygodniku Toruńskim”, czytamy: „Punktualnie o godz. 11-ej zajeżdża na dworzec miejski pociąg wiozący pana Ministra b. dzielnicy pruskiej Władysława Seydę, p. Wojewodę Stefana Łaszewskiego i pana Starostę Krajowego Józefa Wybickiego wraz z ich bliższem otoczeniem. Na dworcu czekają ich komisaryczny Prezydent miasta wraz z delegatami. Po krótkim przemówieniu pana Prezydenta miasta i wymianie słów powitalnych udają się wszyscy samochodami i powozami do gmachu Województwa (dawnej szkoły przemysłowej). Gmach odświętnie przybrany. Na progu sali posiedzeń (dawniejszej auli) wita dostojników chlebem i solą gromadka dzieci, wybranych

20000.00 mk za wykonane dotąd ściany w gmachu Województwa Pomorskiego, APB, UWP w Toruniu, sygn. 23445.

42 Zestawienie kosztów przy przebudówce gmachu szkoły przemysłowej, z dnia 18 czerwca 1920 r., APB, UWP w Toruniu, sygn. 23445.

43 M. Wojciechowski, Powrót Torunia do Polski w 1920 r., s. 5; R. Sudziński, Toruń. Portret miasta, s. 70; B. Mansfeld, Zespół zabytkowy Torunia, Warszawa 1983, s. 9; H. Steinbornowa, Garść wspomnień z dni wkroczenia wojsk polskich do Torunia w roku 1920, „Tygodnik Toruński. Organ urzędowy Magistratu miasta Torunia i Wydziału Powiatowego powiatu Toruńskiego", Toruń, dnia 12 stycznia 1924 r., s. 1-2; eadem, Garść wspomnień z dni wkroczenia wojsk polskich do Torunia w roku 1920 (ciagg dalszy) „Tygodnik Toruński”, Toruń, dnia 19 stycznia 1924 r., s. 1-2; eadem, Garść wspomnień $z$ dni wkroczenia wojsk polskich do Torunia w roku 1920, „Tygodnik Toruński”, Toruń, dnia 26 stycznia 1924 r., s. 1-2; eadem, Garść wspomnień z dni wkroczenia wojsk polskich do Torunia w roku 1920 (ciag dalszy), „Tygodnik Toruński”, Toruń, dnia 9 lutego 1924 r., s. 1-2; eadem, Garść wspomnień z dni wkroczenia wojsk polskich do Torunia w roku 1920 (ciagg dalszy), „Tygodnik Toruński”, Toruń, dnia 16 lutego 1924 r., s. 2; eadem, Garść wspomnień z dni wkroczenia wojsk polskich do Torunia w roku 1920 (ciag dalszy), „Tygodnik Toruński”, Toruń, dnia 23 luty 1924 r., s. 2-3; eadem, Garść wspomnień z dni wkroczenia wojsk polskich do Torunia w roku 1920 (dokończenie), „Tygodnik Toruński”, Toruń, dnia 1 marca 1924 r., s. 2-3; W piąta rocznice wkroczenia wojsk polskich do Torunia, „Tygodnik Toruński”, Toruń, dnia 24 stycznia 1925 r., s. 2-6; T. Zakrzewski, Życie polskie Torunia w ostatnich latach zaboru pruskiego (1916-1920), Toruń 1985, s. 93-95. 
z wśród wszystkich stanów mieszczaństwa" ${ }^{44}$. Siedzibą województwa pomorskiego stał się Toruń, choć wojewoda początkowo urzędował w Poznaniu, a do Torunia przeniósł się 20 stycznia 1920 roku $^{45}$. W pierwszych dniach swej działalności Urząd Wojewódzki mieścił się w Toruniu przy ul. J. Słowackiego nr 15, a następnie został przeniesiony do gmachu byłej Szkoły Przemysłowej przy ul. Fosa Staromiejska nr 3, gdzie pozostał do 1939 roku $^{46}$. Uchwałą z dnia 11 lipca 1924 roku, zatwierdzoną przez Magistrat 17 lipca 1924 roku Rada Miejska przekazała Skarbowi Państwa budynek szkoły „do użytku bezpłatnego w formie rzeczowego prawa użytkowania [...] hipotecznie zapewnionego na czas, dopóki Urząd Wojewódzki swą główną siedzibę w Toruniu zatrzyma, ad. 1/ na kancelarje tegoż urzędu, ad. 2/ na mieszkanie służbowe p. Wojewody"47. W piśmie z dnia 3 lutego 1926 roku, skierowanym do Magistratu miasta Torunia dowiadujemy się, iż z polecenia Sądu Powiatowego w Toruniu do księgi wieczystej Toruń 138 gminy miejskiej wpisano: „prawo bezpłatnego użytkowania nieruchomości na rzecz Pomorskiego Urzędu Wojewódzkiego w Toruniu" ${ }^{48}$. W 1927 roku zaszła potrzeba wymiany centralnego ogrzewania w budynku. Już w lutym powyższego roku sporządzono Kosztorys na powiększenie centralnego ogrzewania w gma-

44 H. Steinbornowa, Garść wspomnień z dni wkroczenia wojsk polskich do Torunia w roku 1920 (ciagg dalszy), „Tygodnik Toruński”, Toruń, dnia 9 lutego 1924 r., s. 2.

45 M.Dereszyńska-Romaniuk, KancelariaUrzędu Wojewódzkiego Pomorskiego $w$ Toruniu w latach 1919-1939, Warszawa 1998, s. 20; Toruń. Krajobraz i architektura, Warszawa 1974, s. 25; B. Rymaszewski, Geneza i rozwój przestrzenny miasta, [w:] Rocznik Toruński, Tom 4, Toruń 1970, s. 184; T. Karczewska, Toruń w okresie międzywojennym i w latach II wojny światowej, w: Torun przewodnik informator, Toruń 1957, s. 17.

46 R. Sudziński, op. cit., s. 70; J. Neumann, Pamiętne dni Torunia. Toruń 18. I. 1920, 1. II. 1945, Toruń 1999, s. 8; Toruń. Miasto i ludzie na dawnej fotografii (do 1939 roku ), op. cit., s. 175; Historia Torunia. W czasach Polski Odrodzonej i okupacji niemieckiej (1920-1945), Tom III, część II, pod red. M. Biskupa, Toruń 2006, s. 117; Toruń 1233-1933. Urzędowy Informator Jubileuszowy, Toruń 1933, s. 6.

47 Odpis uchwały Rady Miejskiej z dnia 11 lipca 1924 r. L:2398 b, APT, AmT, F 1946, K. 14; Odpis uchwały Rady Miejskiej z dnia 11 lipca 1924 r., APB, UWP w Toruniu, sygn. 23445; Pismo z Ministerstwa Spraw Wewnętrznych do Pana Wojewody w Toruniu, $z$ dnia 18 marca 1925 r., APB, UWP w Toruniu, sygn. 23445; APT, AmT, F 1946, K. 4, 6, 7 rewers, 8, 11, 12, 13, 15.

48 APT, AmT, F 1946, K. 16. 
chu Pomorskiego Urzędu Wojewódzkiego ${ }^{49}$. W piśmie z dnia 8 września 1927 roku Stowarzyszenia Dozoru Kotłów w Poznaniu Oddział w Grudziądzu do Wojewody Pomorskiego, Wydział Robót Publicznych w Toruniu, napisano, że: „obecne pomieszczenia w znacznej ilości uformowane zostały przez nowe przepierzenia bez jednoczesnego odpowiedniego podziału grzejników, przeto są pokoje zupełnie bez radiatorów, zaś w pozostałych pomieszczeniach, szczególnie zwróconych na północ, pomimo istniejących grzejników odczuwa się w większości wypadków nieznośne zimno podczas okresu opałowego" "50. Dnia 4 października 1927 roku rozstrzygnięto przetarg na rozszerzenie ogrzewania centralnego ${ }^{51}$. Do przetargu zgłosiły się: firma W i St. Hedinger, mająca swoją siedzibę w Poznaniu na ulicy św. Marcina $27^{52}$, oddział w Poznaniu Towarzystwa Akcyjnego Budowy Maszyn i Urządzeń Sanitarnych Drzewiecki i Jeziorański w Warszawie $^{53}$ oraz Szafranek i Gbiorczyk - fabryka budowy ogrzewań centralnych w Poznaniu. Dwa dni później Wojewoda Pomorski w piśmie do Państwowego Urzędu Budownictwa Naziemnego w Toruniu polecił oddanie robót firmie Szfranek i Gbiorczyk ${ }^{54}$. Dnia 7 października 1927 roku przedsiębiorstwo otrzymało zlecenie na piśmie ${ }^{55}$. W marcu 1928 roku powierzono toruńskiemu mistrzowi dekarskiemu Szczepankiewiczowi naprawę dachu gmachu Urzędu Wojewódzkiego ${ }^{56}$. Dnia 15 kwietnia 1932 roku rozstrzygnięto przetarg na prace dekarskie i blacharskie ${ }^{57}$. Swoje oferty złożyli: E. Klechowicz ${ }^{58}$ i W. Szczepankiewicz. Z korespondencji Bronisława Zielińskiego - palacza w budynku do Oddziału BudżetowoGospodarczego Urzędu Wojewódzkiego Pomorskiego z dnia 21 czerwca 1932 roku $^{59}$ dowiadujemy się o potrzebie kolejnych napraw ogrzewania

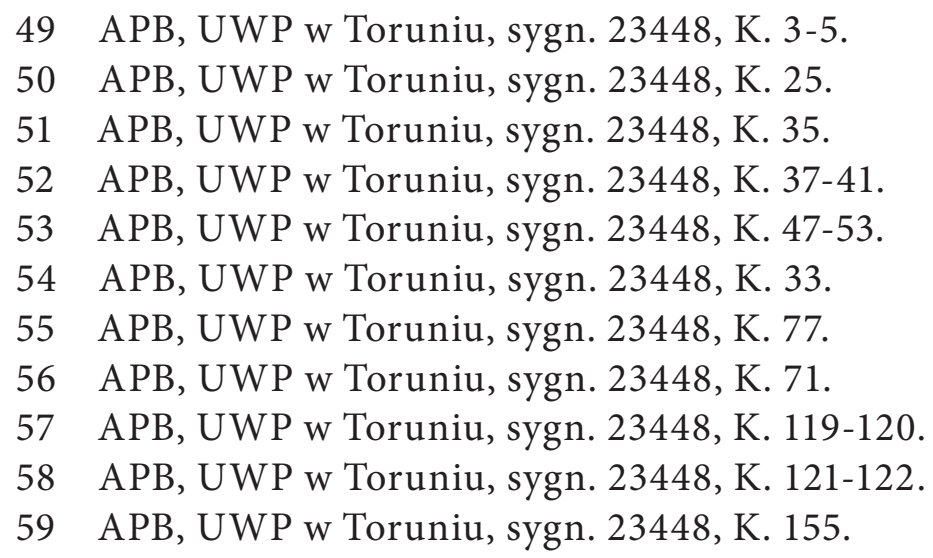


centralnego. Wspomnianym remontem zajęły się Zakłady Instalacyjne - Jan Różański, mające swoją siedzibę w Toruniu przy ul. Słowackiego nr $52^{60}$. W tym czasie zbadano także instalacje kotłów grzewczych. Stwierdzono, iż przestarzałe kotły parowe niskiego ciśnienia należy wymienić ${ }^{61}$. W 1933 roku toruńska firma Hermetic uszczelniała okna $\mathrm{w}$ gabinecie Wojewody $\mathrm{w}$ gmachu Urzędu Wojewódzkiego ${ }^{62}$. Ze sprawozdania z 1 lipca 1937 roku $^{63}$ dowiedzieć się można, że „piorun uderzył w szczyt północny [...] uszkadzając tak szczyt jak i pokrycie dachowe" ${ }^{64}$. Naprawa powyższych uszkodzeń została powierzona firmie Michalak z Torunia ${ }^{65}$.

W artykule pt. Szkolnictwo w Toruniu, z października 1928 roku, autor zauważa, iż „zarząd miasta wytknął sobie za zadanie rozszerzyć szkolnictwo zawodowe, gdy tylko Pomorski Urząd Wojewódzki, który w roku 1920 zajął za zgodą miasta na biura wspaniały i wielki gmach szkoły przemysłowej, w jakim to pomieszczone były szkoły zawodowe najróżniejszych typów, przeniesie się do nowo budującego się w Toruniu gmachu wojewódzkiego" "66. W 1929 roku wzniesiono budynek dla Urzędu Wojewódzkiego na Placu Teatralnym. Gdy był już gotowy wprowadziła się do niego Dyrekcja Kolei Państwowych, przeniesiona do Torunia z Gdańska ${ }^{67}$. Natomiast Pomorski Urząd Wojewódzki pozostał w tym samymgmachu przyul. FasaStaromiejska aż do początku II wojnyświatowej.

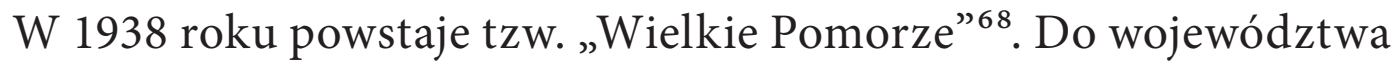
pomorskiego włączono kilka powiatów kujawskich i wielkopolskich, jak:

60 APB, UWP w Toruniu, sygn. 23448, K. 227; APB, UWP w Toruniu, sygn. 23448, K. 239-240.

61 APB, UWP w Toruniu, sygn. 23481, K. 289-290.

62 APB, UWP w Toruniu, sygn. 23448, K. 245.

63 APB, UWP w Toruniu, sygn. 23448, K. 327-328.

64 APB, UWP w Toruniu, sygn. 23448, K. 327.

65 APB, UWP w Toruniu, sygn. 23448, K. 328.

66 Szkolnictwo $w$ Toruniu, w: Ajencja Wschodnia. Przedstawiciele i Korespondenci we wszystkich większych miastach $w$ kraju i zagranica, Toruń, październik 1928 roku, s. 6; Toruń. Monografja miasta, Toruń 1929, s. 56.

67 J. Serczyk, Wspomnienie o Toruniu z czasów Drugiej Rzeczypospolitej 1920-1939, Toruń 1982, s. 16.

68 J. Szczepkowski, Toruń jako ośrodek wojewódzki Polski Północnej, „Rocznik Toruński” 1992, t. XXI, s. 16. 
bydgoski, szubiński, wyrzyski, sępoleński, inowrocławski, rypiński i lipnowski, aleksandrowski, włocławski. Część powiatu brodnickiego i powiat działdowski przeniesione zostały do województwa warszawskiego ${ }^{69}$.

Dnia 1 września 1939 roku nastąpiła agresja Trzeciej Rzeszy na państwo polskie ${ }^{70}$. Toruń został zajęty przez oddziały zbrojne okupanta 7 września 1939 roku $^{71}$. Hitler dekretem z dnia 8 października $1939 \mathrm{r}$. włączył do Rzeszy północne i zachodnie obszary państwa polskiego. $\mathrm{Na}$ obszarze tym ustanowił m.in. jednostkę administracyjną Okręg Rzeszy Gdańsk - Prusy Zachodnie ${ }^{72}$ (Reichsgau Danzig - Westpreussen). W jej skład weszły ziemie byłego województwa pomorskiego (w jego granicach z 1 września 1939 roku), terytorium byłego Wolnego Miasta Gdańska oraz niewielki obszar należący do Niemiec (przed 1 września $1939 \mathrm{roku})^{73}$. W powyższym okręgu dyrekcję policji powołano w Grudziądzu i w Toruniu. Zarządzeniem ministra spraw wewnętrznych Trzeciej Rzeszy Wilhelma Fricka z 13 września 1939 roku zadanie utworzenia w Toruniu państwowego zarządu policyjnego (Staatliche Polizeiverwaltung Thorn) otrzymał SA-Oberführer Schulz-Sembten jako „kommissarischer Polizeiverwalter”. Dopiero jednak zarządzenie ministra Fricka z 6 marca 1940 roku powołało formalnie państwowe zarządy policyjne w Okręgu Rzeszy Gdańsk - Prusy Zachodnie (w tym w Toruniu) i w Kraju Warty z dniem 1 kwietnia. Terytorialne kompetencje tego urzędu obejmowały tylko obszar miasta Torunia. Siedziba państwowego zarządu policyjnego umiejscowiona została $\mathrm{w}$ gmachu przedwojennego Urzędu Wojewódzkiego. Liczba zatrudnionych w nim

69 Historia Pomorza, t. I, s. 45; P. Czaplewski, Związki historyczne między starym i nowym Pomorzem, „Teka Pomorska. Dwumiesięcznik regionalny poświęcony zagadnieniom kultury i sztuki. Organ Konfraterni Artystów w Toruniu”, Toruń, styczeń-kwiecień 1938, Rok III, Nr 1-2 (9-10), s. 1; Toruń w granicach Wielkiego Pomorza. Kilka uwag w sprawie siedziby Władz Państwowych Województwa Pomorskiego, nakładem Komitetu Obywatelskiego m. Torunia, (po 1900), s. 3.

70 Historia Torunia, t. III, część II: W czasach Polski Odrodzonej i okupacji niemieckiej (1920-1945), pod red. M. Biskupa, J. Sziling rozdział XV: Organizacja niemieckich władz okupacyjnych Torunia (1939-1945), Toruń 2006, s. 500.

71 D. Steyer, Toruń w pierwszych miesiacach okupacji hitlerowskiej (wrzesieńgrudzień 1939 r.), „Rocznik Toruński” 1971, t. V, s. 127.

72 Historia Torunia, t. III, część II, s. 500.

73 D. Steyer, Toruń w pierwszych miesiącach okupacji hitlerowskiej, s. 119. 
pracowników wynosiła około 100 osób ${ }^{74}$. Zachowała się korespondencja z 7 lutego 1940 r. dotycząca uszkodzeń budynku spowodowanych, zdaniem Państwowej Administracji Policyjnej, przeprowadzanym w tym czasie wysadzaniem bunkra nr 17. Burmistrz miasta Torunia nie uznał roszczeń co do udzielenia odszkodowania. Zalecił wcześniej dokładne oględziny obiektu, podczas których stwierdzono, że rysy i pęknięcia murów powstały na skutek osiadania budynku oraz pracy materiałów budowlanych ${ }^{75}$. Z odpisu dokumentu z 2 października 1942 roku dowiadujemy się o chęci zabezpieczenia pomieszczeń piwnicznych, w których znajdowała się centrala telefoniczna. Państwowy Urząd Budowlany w Toruniu (Reichsbauamt Thorn) zamierzał: „1. Zamurować od strony zewnętrznej okna od pomieszczeń łączności i wybierania rozmów pozostawiając przy tym mały otwór, który w czasie zagrożenia będzie mógł być zamykany przy pomocy żelaznych drzwi. Poza tym otwór ten będzie dostarczał dodatkowe oświetlenie, wymianę powietrza i będzie awaryjnym wyjściem ewakuacyjnym. 2. Postawić od strony ulicy ceglaną ścianę przed oknami akumulatorowni, maszynowni i radia o grubości $51 \mathrm{~cm}$, długości 11,4 m i wysokości 2,70 m co pozwoli zachować pierwotny wygląd budynku"76. Dnia 27 października 1942 roku Przewodniczący Okręgu Regencyjnego udzielił pozwolenia na wyżej wymienione przedsięwzięcia budowlane ${ }^{77}$. Dnia 18 listopada 1942 roku Państwowy Urząd Budowlany w Toruniu (Reichsbauamt Thorn) przesłał do Burmistrza miasta Torunia Urząd Policji Budowlanej do wglądu nowe rysunki z naniesionymi ścianami ochrony przeciwodłamkowej, przy oknach centrali telefonicznej Państwowej Dyrekcji Policji w Toruniu ${ }^{78}$.

Rozkazem z 30 stycznia 1940 roku Główny Urząd SS dokonał rozmieszczenia terytorialnego jednostek stacjonujących na Pomorzu Gdańskim. Siedziba dowództwa SS mieściła się w Toruniu początkowo

74 Historia Torunia, t. III, część II, s. 532, 533.

75 APT, AmT, G 715, K. 1.

76 APT, AmT, G 715, K. 3.

77 APT, AmT, G 715, K. 6.

78 APT, AmT, G 715, K. 8. 
przy ul. Moniuszki nr 10, a od 20 września 1944 roku przeniesiona została do budynku dyrekcji policji przy ul. Fosa Staromiejska nr $3^{79}$.

Toruń odzyskał wolność 1 lutego 1945 roku $^{80}$. Dnia 24 sierpnia 1945 roku Rada Ministrów uchwaliła, a Prezydium Krajowej Rady Narodowej zatwierdziło dekret o utworzeniu Uniwersytetu Mikołaja Kopernika w Toruniu ${ }^{81}$. Główne gmachy Uniwersytetu skupiały się w obrębie Starego Miasta lub w jego najbliższym sąsiedztwie ${ }^{82}$. Po wielomiesięcznych staraniach UMK otrzymał dwa główne obiekty dydaktyczne: dawny gmach Urzędu Wojewódzkiego (Collegium Maius) przy Fosie Staromiejskiej nr 3 oraz budynek byłej Komunalnej Kasy Oszczędności przy tej samej ulicy (Collegium Minus) ${ }^{83}$. Pierwszy Rektor Uniwersytetu Ludwik Kolankowski, w publikacji pt. Powstanie i organizacja Uniwersytetu, pisze: "gmachem, zwolnionym dla nas [dla UMK] przez szpital wojskowy dn. 18 XI 1945 r., był bardzo zniszczony budynek dawnego Urzędu Wojewódzkiego, odremontowany w porze zimowej. Gmach ten - tzw. Collegium Maius - użyty został na pomieszczenie rektoratu, dziekanatów, skromnej auli (dziś sali posiedzeń senatu) oraz na lokale wykładowe Wydziału Humanistycznego, a częściowo i Wydziału Sztuk Pięknych"84. Z pisma S. Chmarzyńskiego, Intendenta Uniwersytetu, do Zarządu Miejskiego Wydziału Technicznego

79 Historia Torunia, t. III, część II, s. 525.

80 H. S. Kamiński, Władysław Dobrowolski prezydent miasta Torunia w latach 1945-1949, „Rocznik Toruński” 1990, t. XIX, s. 73.

81 L. Kolankowski, Powstanie i organizacja Uniwersytetu, w: Uniwersytet Mikołaja Kopernika 1945-1955, red. naczelny: R. Galon, Warszawa 1957, s. 14; S. Kalembka, Dwieście lat Sztuk Pięknych na Uniwersytetach $w$ Wilnie i Toruniu 1797-1997. Szkice, Toruń 1998, s. 37; T. Karczewska, Toruń współczesny, w: Toruń. Przewodnik informator, Warszawa 1957, s. 21; R. Sudziński, Toruń. Portret miasta, s. 85; J. Staszewski, 55 lat Uniwersytetu Mikołaja Kopernika, „Rocznik Toruński” 2001, t. XXVIII, s. 26; Toruń dawny i dzisiejszy, s. 579.

82 Z. Michno-Zatorska, Anegdoty, wspominki i refleksje z pierwszego ćwierćwiecza UMK, Toruń 1996, s. 22.

83 J. Bełkot, Uniwersytet Mikołaja Kopernika w Toruniu w latach 1945-1985, Toruń 1986, s. 38 .

84 L. Kolankowski, Powstanie i organizacja Uniwersytetu, s. 19; R. Bäcker, H. Duczkowska-Moraczewska, J. Gzella, R. Jadczak, J. Staszewski, Kronika 35-lecia, „Głos Uczelni. Biuletyn Uniwersytetu Mikołaja Kopernika. 35 lat UMK”, Toruń 1980, s. 99. 
w Toruniu, z dnia 9 listopada 1945 roku, dowiadujemy się o prowadzonych pod kierownictwem Stefana Smolnego, pracach budowlanych w gmachu byłego Urzędu Wojewódzkiego ${ }^{85}$. Uchwałą z dnia 9 września 1946 r., nr 539, Zarząd Miejski postanowił wydzierżawić Uniwersytetowi Mikołaja Kopernika gmach przy ul. Fosa Staromiejska nr 3, z czynszem, ustalonym przez Wydział Techniczny. Kwota czynszowa miała być zaliczona jako subwencja dla Uniwersytetu ${ }^{86}$.

W piśmie rektora UMK Ludwika Kolankowskiego do Władysława Dobrowolskiego, prezydenta Torunia, z dnia 20 stycznia 1947 roku, czytamy: „proszę Pana Prezydenta, by zechciał spowodować odpowiednią uchwałę MRN Torunia, przekazującą budynek tzw. Collegium Maius przy ul. Fosa Staromiejska 3 na własność Uniwersytetu. Praktycznie będzie to równoznaczne $\mathrm{z}$ darowaniem Uniwersytetowi corocznie czynszu, ale dla prestiżu Uniwersytetu i jego prawnego stanu stanowi to

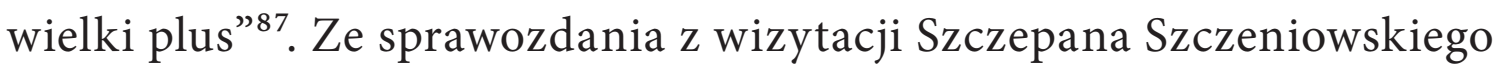
(wizytatora z ramienia Sekcji Organizacji Szkolnictwa Wyższego Rady Głównej), sporządzonego 29 kwietnia 1948 roku, dowiadujemy się m.in., że: „UMK rozporządza obecnie 9 budynkami. Są to: Collegium Maius (Fosa Staromiejska 3), mieszczące biura uniwersyteckie i zakłady naukowe Wydziału Humanistycznego oraz częściowo Wydziału Sztuk Pięknych; budynek jest wydzierżawiony od Zarządu Miejskiego i obejmuje 8 sal wykładowych, 50 lokali seminaryjnych i zakładowych, 26 lokali biurowych i 4 pokoje gospodarcze. Budynek zawiera prócz tego 4 mieszkania służbowe o 7 pokojach" 88 .

W auli Collegium Maius od samego początku odbywały się uroczystości uniwersyteckie, m.in. inauguracje roku akademickiego. W październiku 1965 roku spisano Generalne założenia inwestycji rozwoju Uniwersytetu Mikołaja Kopernika w Toruniu w latach 1961-1980, z których dowiadujemy się, że w piwnicach budynku znaj-

85 APT, AmT, G 716, K. 47.

86 APT, AmT, G 716, K. 66.

87 Powstanie $i$ pierwsze dziesięć lat Uniwersytetu Mikołaja Kopernika 1945-1956. Wybór źródeł, wydała H. Duczkowska-Moraczewska, Źródła do dziejów Uniwersytetu Mikołaja Kopernika w Toruniu, t. I, Toruń 1995, s. 154.

88 Ibidem, s. 174-176. 
dowała się „introligatornia wraz z drukarnią oraz część magazynów centralnych Uczelni"89.

W 1957 roku została sporządzona inwentaryzacja budynku Collegium Maius ${ }^{90}$. W planie remontów na tenże rok figuruje zestawienie prac, jakie powinny być wykonane, m.in. przebudowa instalacji centralnego ogrzewania, przemurowanie kominów i murów attyki, remont pokrycia dachowego oraz rynien, malowanie korytarzy, sal wykładowych oraz pomieszczeń dydaktycznych, malowanie okien, zwiększenie oświetlenia w salach wykładowych i dydaktycznych, naprawa instalacji wodno-kanalizacyjnej, izolacja rur centralnego ogrzewania, naprawa stolarki okiennej i drzwiowej, prace zduńskie ${ }^{91}$. Z uzasadnienia do powyżej wypisanych remontów dowiedzieć się można, iż instalacja centralnego ogrzewania, niezmieniana od 1909 roku, wymagała kapitalnej przebudowy. Wystające mury attyki i głowic kominowych ponad dachem zagrażały bezpieczeństwu publicznemu, zaś część wschodnia budynku, zdaniem Miejskiej Komisji Budowlanej, groziła zawaleniem ${ }^{92}$. W planie remontów bieżących i średnich na lata 1956-1960, przedstawiono dokładne zestawienie sum, jakie Uniwersytet będzie musiał zapłacić za prace remontowe w wyżej wymienionym czasie ${ }^{93}$. Dnia 10 marca 1961

89 Generalne założenia inwestycji rozwoju Uniwersytetu Mikołaja Kopernika w Toruniu w latach 1961-1980, dokument spisany w październiku 1965, podpisany przez: Rektora, prof. dr. W. Łukaszewicza, Seniora rozbudowy UMK - prof. dr. A. Swinarskiego, opracowany w Pracowni S 77 Katedry Podstaw Budowy Miast Wydział Architektury Politechniki Warszawskiej, podpisali: doc. dr R. Karłowicz, autorzy założeń: mgr E. Kosiacki, mgr M. Kaczmarek, we współpracy z: mgr inż. M. Szczypiorską, mgr. inż. J. Mołoniewiczem, mgr. inż. S. Wolskim, mgr inż. K. Mickiewicz. Niniejsze założenia zostały zatwierdzone decyzją Ministra Szkolnictwa Wyższego z dnia 29 września 1966 r., Archiwum Uniwersytetu Mikołaja Kopernika, Generalne założenia inwestycji rozwoju Uniwersytetu Mikołaja Kopernika w Toruniu w latach 1961-1980, sygn. Zarząd Inwestycji - 16/53, s. 70, 74.

90 Opis techniczny Bd-T-459/56, A.UMK, Dokumentacja techniczna Collegium Maius, sygn. Dział Techniczny 10/274.

91 Zestawienie planu remontów bieżących i średnich na rok 1957, A.UMK, Plan remontów na 1957 r., sygn. DT-3/9.

92 Uzasadnienie do zestawienia planu remontów bieżacych i średnich na rok 1957, A.UMK, Plan remontów na 1957 r., sygn. DT-3/9.

93 Plan remontów bieżacych i średnich na rok 1956 do 1960 roku, A.UMK, Plany remontów kapitalnych i bieżacych $w$ l. 1956-1962, sygn. DT-1/3. 
roku Rektorat Uniwersytetu Mikołaja Kopernika zlecił wykonanie robót remontowo-budowlanych i instalacyjnych w budynkach uczelni, także w Collegium Maius, Toruńskiej Spółdzielni Pracy RemontowoBudowlanej ${ }^{94}$. Na początku 1962 r. Rzemieślnicza Spółdzielnia Zaopatrzenia i Zbytu Branży Metalowej z Torunia wystawiła rachunek na przeprowadzone przez nią prace remontowe dachu budynku (zlecenie z 1 lipca 1961 roku) ${ }^{95}$. Z rachunku z października 1962 roku dowiadujemy się o pracach malarskich prowadzonych w gmachu przez Rzemieślniczą Spółdzielnię Zaopatrzenia i Zbytu Branży DrzewnoBudowlanej ${ }^{96}$. Ta sama firma wykonywała remont dachu ${ }^{97}$ oraz prace remontowo-budowlane we wnętrzu budynku ${ }^{98}$. W tym samym roku przeprowadzano także m.in., remont instalacji centralnego ogrzewania (Spółdzielnia Pracy Pracowników Przemysłu Metalowego w Toruniu) ${ }^{99}$. W Planie remontów budynków Uczelni na rok 1962 odnotowano też, iż od 1 do 30 marca 1962 roku zakładano nową instalację elektryczną w sali senatu Collegium Maius ${ }^{100}$. W 1963 roku w budynku przeprowadzono m.in. prace malarskie, dekarskie, murarskie, ciesielskie, zduńskie, wodno-kanalizacyjne, elektryczne ${ }^{101}$. W Planie remontów bieżacych budynków Uczelni na rok 1964 Rozdz. $40 \$ 8 a$, pod nr 1, figuruje budynek Collegium Maius, w którym należało wykonać remont instalacji elektrycznej, montaż kotłów c.o. oraz roboty malarskie i dekarskie ${ }^{102}$.

94 Pismo z dnia 10 marca 1961 do Toruńskiej Spółdzielni Pracy RemontowoBudowlanej, A.UMK, Remonty bieżace 1962, sygn. DT-4/28 (a).

95 Rachunek nr 117/62 wystawiony 5 lutego 1962 r., A. UMK, Remonty bieżace (1962 r.), sygn. DT-4/28 (a).

96 Rachunek nr 1013 wystawiony 12 października 1962 r., A. UMK, Remonty bieżące (1962 r.), sygn. DT-4/28 (a).

97 Rachunek nr 938 wystawiony 24 września 1962 r., A. UMK, Remonty bieżace (1962 r.), sygn. DT-4/28 (a).

98 Rachunek nr 834 wystawiony 31 sierpnia 1962 r., A. UMK, Remonty bieżace (1962 r.), sygn. DT-4/28 (a).

99 Rachunek nr 1001/9/A/62 z 17 września 1962 r., A. UMK, Remonty bieżące (1962 r.), sygn. DT-4/28 (a).

100 Plan remontów budynków Uczelni na rok 1962, A. UMK, Plan remontów bieżacych na rok 1962, sygn. DT-4/1.

101 Karta remontu budynku, A.UMK, Remonty 1963 r., sygn. DT-4/29 (a).

102 Plan remontów bieżacych budynków Uczelni na rok 1964 Rozdz. 40 \$ 8a, A. UMK, Plan remontów bieżacych 1964 r., sygn. DT-4/3. 
W 1965 roku przeprowadzano także prace malarskie, dekarskie, budowlane, elektryczne itp. ${ }^{103}$ Z protokołu z 19 stycznia 1966 roku w sprawie ofert na roboty malarskie, czytamy, iż komisja postanowiła przyjąć ofertę Rzemieślniczej Spółdzielni Zaopatrzenia i Zbytu Branży Drzewno-Budowlanej w Toruniu ${ }^{104}$. Z pisma z 26 lipca 1967 roku do Ministerstwa Oświaty i Szkolnictwa Wyższego Departament Finansowo-Ekonomiczny dowiadujemy się, że w czasie silnych burz, w czerwcu powyższego roku, zostały zalane dolne kondygnacje niektórych budynków uniwersyteckich, m.in. Collegium Maius ${ }^{105}$. Plan remontów bieżacych $i$ konserwacji na rok 1968 zawiera spis prac, jakie należało wykonać w budynku, m.in. roboty instalacyjno-montażowe c.o., częściowy remont pokrycia dachowego, malowanie stolarki okiennej i niektórych pomieszczeń ${ }^{106}$. W 1969 r. wykonywano remont instalacji c..$^{107}$, a także roboty budowlane, stolarskie, tynkowe, murarskie ${ }^{108}$, dekarskie $^{109}$ oraz prace malarskie ${ }^{110}$.

103 Karta remontu budynku, A. UMK, Remonty 1965 r., sygn. DT-4/31 (a).

104 Protokół z 19 stycznia 1966 r., A.UMK, Remonty (1966 r.), sygn. DT-4/32 (b).

105 Pismo $z$ dnia 26 lipca 1967 r. do Ministerstwa Oświaty i Szkolnictwa Wyższego Departament Finansowo-Ekonomiczny, A. UMK, Plan remontów kapitalnych 1967, sygn. DT-1/7.

106 Plan remontów bieżacych i konserwacji na rok 1968, A. UMK, Plan remontów bieżacych naukowo dydaktycznych 1968, sygn. DT-4/12.

107 Protokót odbioru wykonanych elementów, robót, obiektu z dnia 22 maja 1969 r., A.UMK, Remonty (1969 r.), sygn. DT-4/35 (a); Protokół odbioru wykonanych elementów, robót, obiektu $z$ dnia 7 listopada 1969 r., A.UMK, Remonty (1969 r.), sygn. DT-4/35 (a); Protokół odbioru wykonanych elementów, robót, obiektu $z$ dnia 6 grudnia1969 r., A.UMK, Remonty (1969 r.), sygn. DT-4/35 (a).

108 Protokół odbioru wykonanych elementów, robót, obiektu $z$ dnia 31 stycznia 1969 r., A.UMK, Remonty (1969 r.), sygn. DT-4/35 (a); Protokół odbioru wykonanych elementów, robót, obiektu z dnia 28 lutego 1969 r., A.UMK, Remonty (1969 r.), sygn. DT-4/35 (a).

109 Protokół odbioru wykonanych elementów, robót, obiektu $z$ dnia 30 sierpnia 1969 r., A.UMK, Remonty (1969 r.), sygn. DT-4/35 (a); Protokół odbioru wykonanych elementów, robót, obiektu z dnia 30 września 1969 r., A.UMK, Remonty (1969 r.), sygn. DT-4/35 (a); Protokół odbioru wykonanych elementów, robót, obiektu $z$ dnia 29 listopada 1969 r., A.UMK, Remonty (1969 r.), sygn. DT-4/35 (a).

110 Protokól odbioru wykonanych elementów, robót, obiektu $z$ dnia 30 czerwca 1969 r., A.UMK, Remonty (1969 r.), sygn. DT-4/35 (a); Rachunek nr 3013 a z dnia 23 grudnia 1969 r. za wykonane prace malarskie, A.UMK, Remonty (1969 r.), sygn. DT$4 / 35$ (a). 
W kolejnych latach również przeprowadzano remonty w gmachu Collegium Maius ${ }^{111}$. W 1972 roku planowano malowanie pomieszczeń, korytarzy i sanitariatów oraz prace elektryczne i instalacyjne ${ }^{112}$. W 1973 roku wykonywano prace malarskie, montażowe, dekarskie i budowlane ${ }^{113}$. W sprawozdaniu sporządzonym dnia 26 sierpnia 1974 roku wspomniano o remontach przeprowadzanych, w tym czasie, $\mathrm{w}$ budynku ${ }^{114}$. Pomalowano wówczas pomieszczenia po magazynach, klatki schodowe i zewnętrzną stolarkę okienną, wyremontowano instalację elektryczną, naprawiano kotły i zamontowano instalacje c.o., wykonywano naprawy pokrycia dachu, częściowo wymieniano rynny i rury spustowe, wycyklinowano parkiety ${ }^{115}$. W latach $1975-1981 \mathrm{w}$ dalszym ciągu prowadzono prace remontowe (budowlane, malarskie, dekarskie, elektryczne itp. $)^{116}$. Z Planu remontów bieżacych pomieszczeń

111 Plan rzeczowo-finansowy konserwacji i remontów bieżacych na rok 1970, A.UMK, Plany remontów 1970-1974, sygn. DT-9/37 b; Plan remontów bieżących i konserwacji budynków Uczelni na rok 1971, A.UMK, Plany remontów 1970-1974, sygn. DT9/37 b; Zaktualizowany plan remontów budynków dydaktycznych Uniwersytetu Mikołaja Kopernika w Toruniu na rok 1971, A.UMK, Plany remontów 1970-1974, sygn. DT-9/37 b.

112 Plan remontów i konserwacji budynków Uczelni na rok 1972, A.UMK, Plany remontów 1970-1974, sygn. DT-9/37 a; Plan rzeczowo-finansowy remontów i konserwacji budynków Uczelni na rok 1972, A.UMK, Plany remontów 1970-1974, sygn. DT-9/37 a.

113 Plan remontów i konserwacji budynków naukowo-dydaktycznych UMK na rok 1973, A.UMK, Plany remontów 1970-1974, sygn. DT-9/37 a.

114 Sprawozdanie sporzadzone 26 sierpnia 1974 r., A.UMK, Plany remontów 1970-1974, sygn. DT-9/37 a.

115 Plan remontów i konserwacji budynków naukowo-dydaktycznych UMK na rok 1974, A.UMK, Plany remontów 1970-1974, sygn. DT-9/37 a; Plan rzeczowo-finansowy remontów i konserwacji budynków Uczelni na 1974 rok, A.UMK, Plany remontów 1970-1974, sygn. DT-9/37 a.

116 Plan remontów i konserwacji budynków dydaktycznych Uczelni na rok 1975, A.UMK, Plany remontów 1975-1976, sygn. DT-9/38 a; Plan remontów i konserwacji budynków dydaktycznych Uczelni na rok 1976, A.UMK, Plany remontów 1975-1976, sygn. DT-9/38 a; Plan rzeczowo-finansowy konserwacji i remontów bieżacych na 1977 rok, A.UMK, Plany remontów 1977-1979, sygn. DT-9/38 b; Plan rzeczowo-finansowy konserwacji i remontów bieżacych na 1978 rok, A.UMK, Plany remontów 1977-1979, sygn. DT-9/38 b; Plan rzeczowo-finansowy konserwacji i remontów bieżacych na 1979 rok, A.UMK, Plany remontów 1977-1979, sygn. DT-9/38 b; Plan rzeczowo-finansowy konserwacji i remontów bieżacych na 1980 rok, A.UMK, Plany remontów 1980-1981, sygn. DT-9/38 c; Plan rzeczowo-finansowy konserwacji i remontów bieżacych na 1981 rok, A.UMK, Plany remontów 1980-1981, sygn. DT-9/38 c. 
w budynkach $i$ zakładach na rok 1981 dowiadujemy się, iż od 1 lipca do 30 sierpnia 1981 r. malowano ściany, okna i podłogę w Sali Senatu Collegium Maius ${ }^{117}$. W 1982 roku wykonywano m.in. remont dachu, bramy wejściowej, malowano sale wykładowe, uzupełniano izolację termiczną przewodów c.o. ${ }^{118}$. W lipcu 1983 roku Biuro ProjektowoBadawcze Budownictwa Ogólnego MIASTOPROJEKT - Toruń sporządziło dokumentację techniczną kwartałów „H”, „Ha”, „Hb” zespołu staromiejskiego w Toruniu. W załączniku 25 i 26 opisano stan techniczny budynku Collegium Maius ${ }^{119}$. W latach osiemdziesiątych zmieniono wystrój obecnej sali im. L. Kolankowskiego. W 1985 roku zamontowano w jej oknach witraże, których projekty sporządzili: T. Urbanowicz i G. Żabicki z Wrocławia, a wykonali je: M. Kruszczewska i A. Kałucki z Pracowni Witrażu UMK w Toruniu ${ }^{120}$. Na ścianach wisiały portrety Rektorów Uniwersytetu, które w 2004 roku zostały przeniesione do Collegium Maximum. W 1995 roku wymieniano instalację elektryczną w gmachu Collegium Maius oraz wykonywano prace malarskie ${ }^{121}$. Rok później wymieniono rynny i rury spustowe ${ }^{122}$. W 1998 i w 2000 r. remontowano stolarkę okienną. Rok później modernizowano instalację wodno-kanalizacyjną i elektryczną ${ }^{123}$. W 2002 roku sporządzono projekt architektoniczno-budowlany remontu elewacji, dachu i likwidacji zawilgoceń piwnic ${ }^{124}$. W następnym roku rozpoczęto remont elewacji, prowadzony sukcesywnie w latach 2005-2007. W 2006 i 2007 roku wy-

117 Plan remontów bieżących pomieszczeń $w$ budynkach i zakładach na rok 1981, A.UMK, Plany remontów 1980-1981, sygn. DT-9/38 c.

118 Plan rzeczowo-finansowy konserwacji i remontów bieżacych na 1982 rok, A.UMK, Plany remontów 1982, sygn. DT-9/38 d.

119 Dokumentacja techniczna kwartałów „H”, „Ha”, „Hb” zespołu staromiejskiego w Toruniu, Biuro Projektowo-Badawcze Budownictwa Ogólnego MIASTOPROJEKT - Toruń, Archiwum Miejskiego Konserwatora Zabytków, sygn. 382 H/1.

120 Inskrypcja dotycząca autorów projektu i wykonawców witraży znajduje się w dolnym fragmencie wschodniego okna w sali im. L. Kolankowskiego.

121 Informacje uzyskane w Dziale Remontów UMK w Toruniu.

122 Karta ewidencyjna zabytków architektury i budownictwa, nr 1820.

123 Informacje uzyskane w Dziale Remontów UMK w Toruniu.

124 Biuro Projektów Architektury AREA, Projekt architektoniczno-budowlany remontu elewacji, dachu, likwidacji zawilgoceń piwnic, opracował mgr inż. arch. P. Dąbrowski, Toruń 2002 r., Archiwum Miejskiego Konserwatora Zabytków, sygn. 2732. 
mieniono także pokrycie dachowe ${ }^{125}$. W 2007 roku rozpoczęto realizację programu mającego na celu kompleksową konserwację i restaurację sali im. L. Kolankowskiego. W owym czasie Zakład Konserwacji Elementów i Detali Architektonicznych Wydziału Sztuk Pięknych UMK wykonał konserwację kamiennych obramień okiennych, zaś zespół konserwatorów (mgr Solida Lim, mgr Magdalena Gabinet, mgr Jarosław Dąbrowski, mgr Joanna Zyzik, mgr Paulina Gref, studenci II i IV roku Zakładu Konserwacji Malarstwa i Rzeźby Polichromowanej Wydziału Sztuk Pięknych UMK), pod kierunkiem prof. Bogumiły Rouba, przeprowadził konserwację i restaurację drewnianego stropu polichromowanego znajdującego się w sali ${ }^{126}$.

W 2008 roku zespół (mgr Jarosław Dąbrowski, mgr Marcin Fausek, mgr Barbara Maria Gawęcka, mgr Paulina Gref, mgr Magdalena Kapka, mgr Joanna Kozielec, mgr Anna Łojkuć-Celep, mgr Justyna Marcinkowska, mgr Ewa Pietrzykowska, mgr Marta Stefanicka, mgr Bożena Szmelter-Fausek, mgr Ludmiła Tymińska-Widmer, Monika Kwiatkowska, Kamila Matwiejszyn, Karolina Pyrkosz, Monika Suprun, Agata Warszewska) pod kierunkiem prof. Bogumiły Rouba, przy współpracy mgr Jolanty Korcz, mgr Solidy Lim, wykonał konserwację i restaurację malowideł w sali im. L. Kolankowskiego. Podczas owych prac odkryto dekorację malarską, którą można podzielić na trzy grupy:

1. Dekoracja powstała w okresie, gdy w budynku mieściła się Szkoła Przemysłowa - lata 1906/1907-1920: wimpergi flankowane pinaklami.

2. Dekoracja powstała $\mathrm{w}$ okresie międzywojennym, w czasie, gdy gmach zajmował Wojewódzki Urząd Pomorski - lata 1920-1939: herb Pomorza (czerwony gryf), lamperia, złożona z naprzemian umieszczonymi w kwaterach, orłami mieczowymi (herbami województw chełmińskiego i malborskiego oraz Prus Królewskich) i gryfami (herbami województwa pomor-

125 Informacje uzyskane w Dziale Remontów UMK w Toruniu.

126 Dokumentacja prac konserwatorskich i restauratorskich. Drewniany strop polichromowany, XIX/XX w., w auli im. prof. Kolankowskiego w Collegium Maius UMK $w$ Toruniu, autor dokumentacji: S. Lim, Toruń 2007 r., s. 7. 
skiego), dwa godła Polski, przedstawienia ukazujące budowę mostu (?) oraz dziewczynę z rybami.

3. Dekoracja powstała w czasie II wojny światowej: herby miast:

Toruń, Gdańsk (?), Bydgoszcz, Chojnice (?), swastyka, herb III Rzeszy, symbol SS ${ }^{127}$.

Dokładny opis malowideł i ich konserwacji stanowić będzie temat odrębnego artykułu.

127 Dokumentacja prac konserwatorskich i restauratorskich. Malowidła ścien$n e w$ auli im. Ludwika Kolankowskiego w Collegium Maius Uniwersytetu Mikołaja Kopernika w Toruniu (XX w.). Autor prac konserwatorskich i restauratorskich: zespół artystów konserwatorów dzieł sztuki, pod kierunkiem: prof. zw. dr kwal. II st. Bogumiły Rouba, mgr Jolanty Korcz, mgr Solidy Lim, autor dokumentacji, mgr Ludmiła Tymińska-Widmer, autorzy badań specjalistycznych: badania historyczne - mgr Barbara Maria Gawęcka, badania budowy technicznej - mikrofotografie przekrojów próbek w świetle VIS i UV - dr Zuzanna Rozłucka, Toruń 2008. 


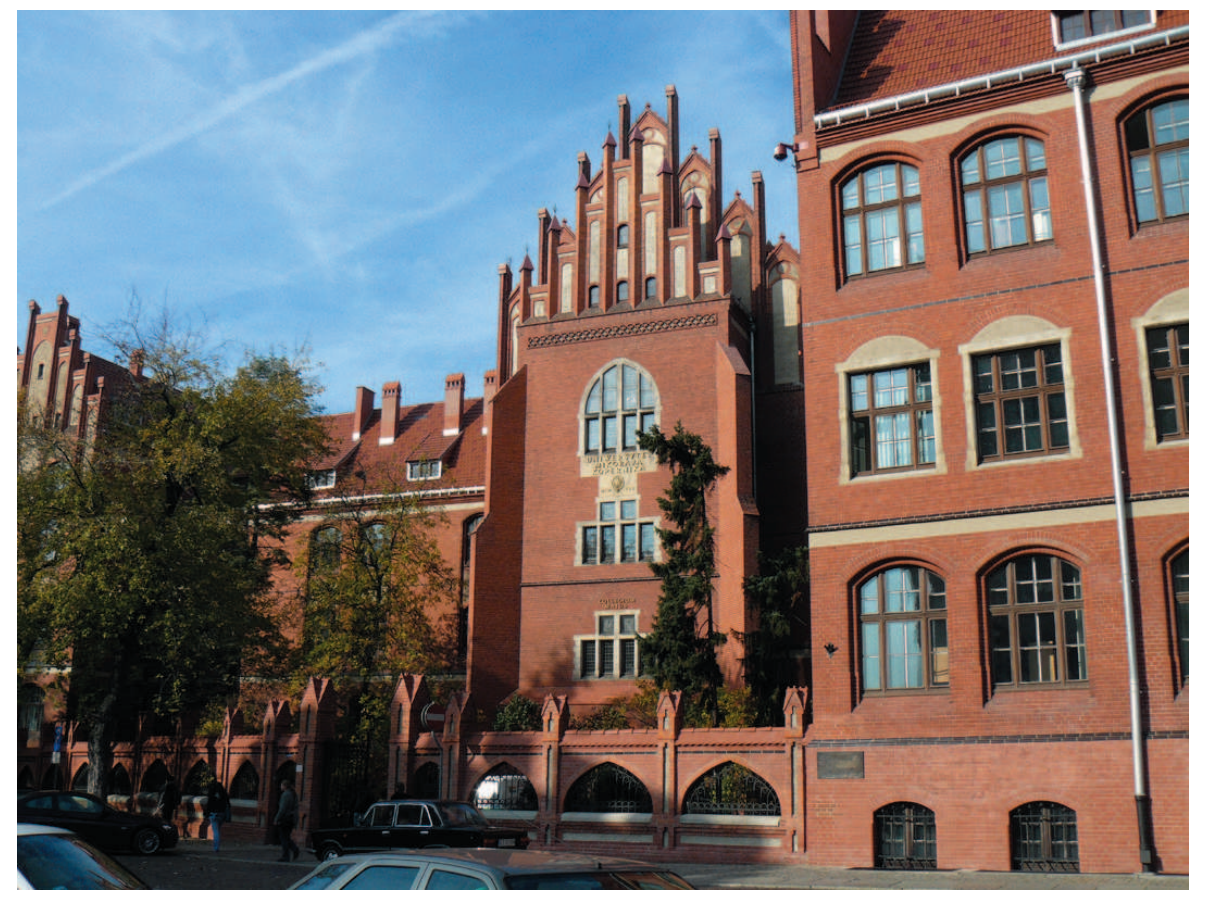

Il. 1. Collegium Maius, elewacja od strony południowej, 2009 r. (fot. B. M. Gawęcka)

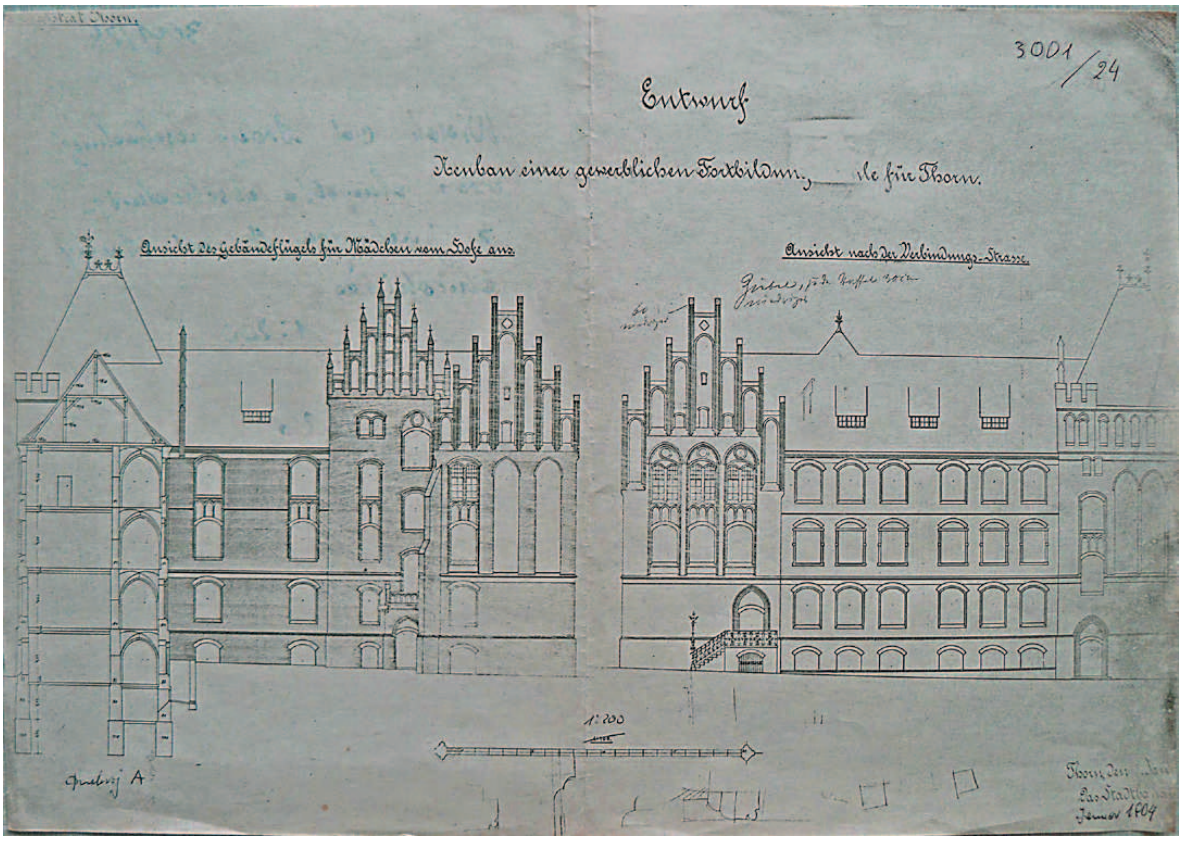

Il. 2. Szkoła Przemysłowa, widok od strony wschodniej oraz skrzydła wschodniego z przekrojem "A” od strony dziedzińca, 1:200, 1904 r., kopia; projekt w posiadaniu Kierownika Obiektu Dydaktycznego Collegium Maius UMK w Toruniu 


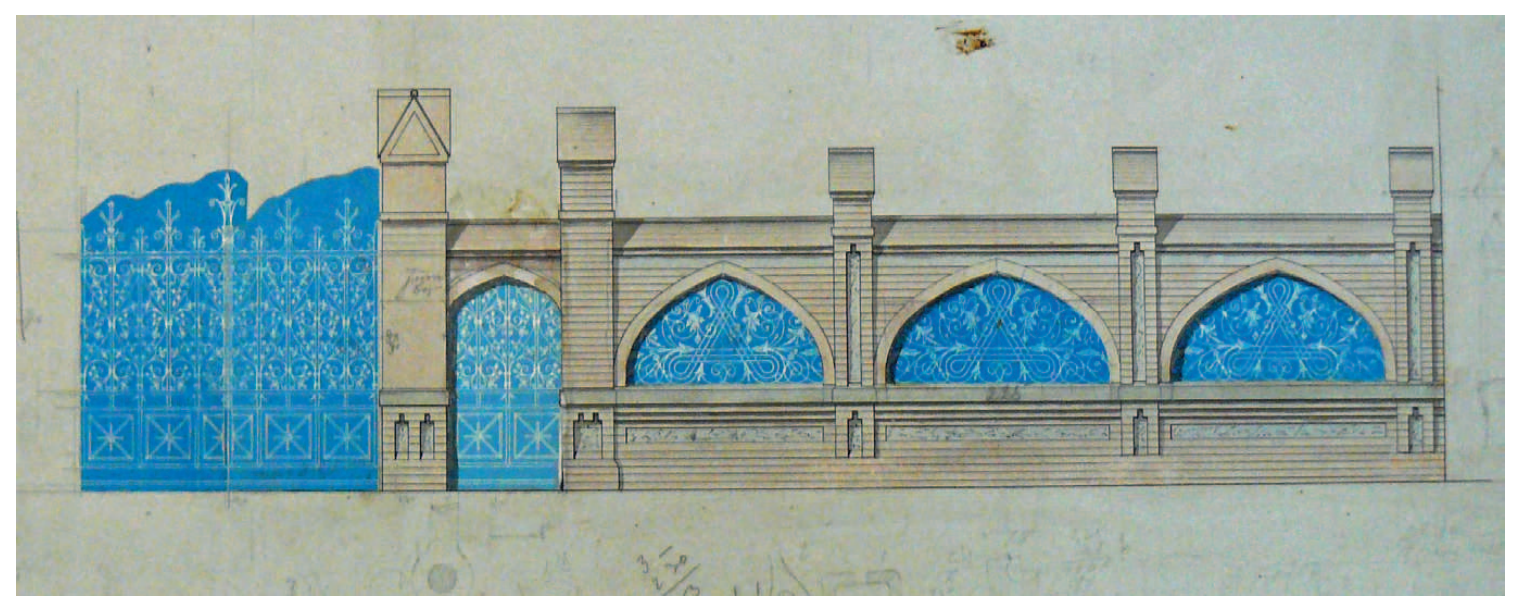

Il. 3. Szkoła Przemysłowa, projekt ogrodzenia, APT, AmT, T 47, K. 1

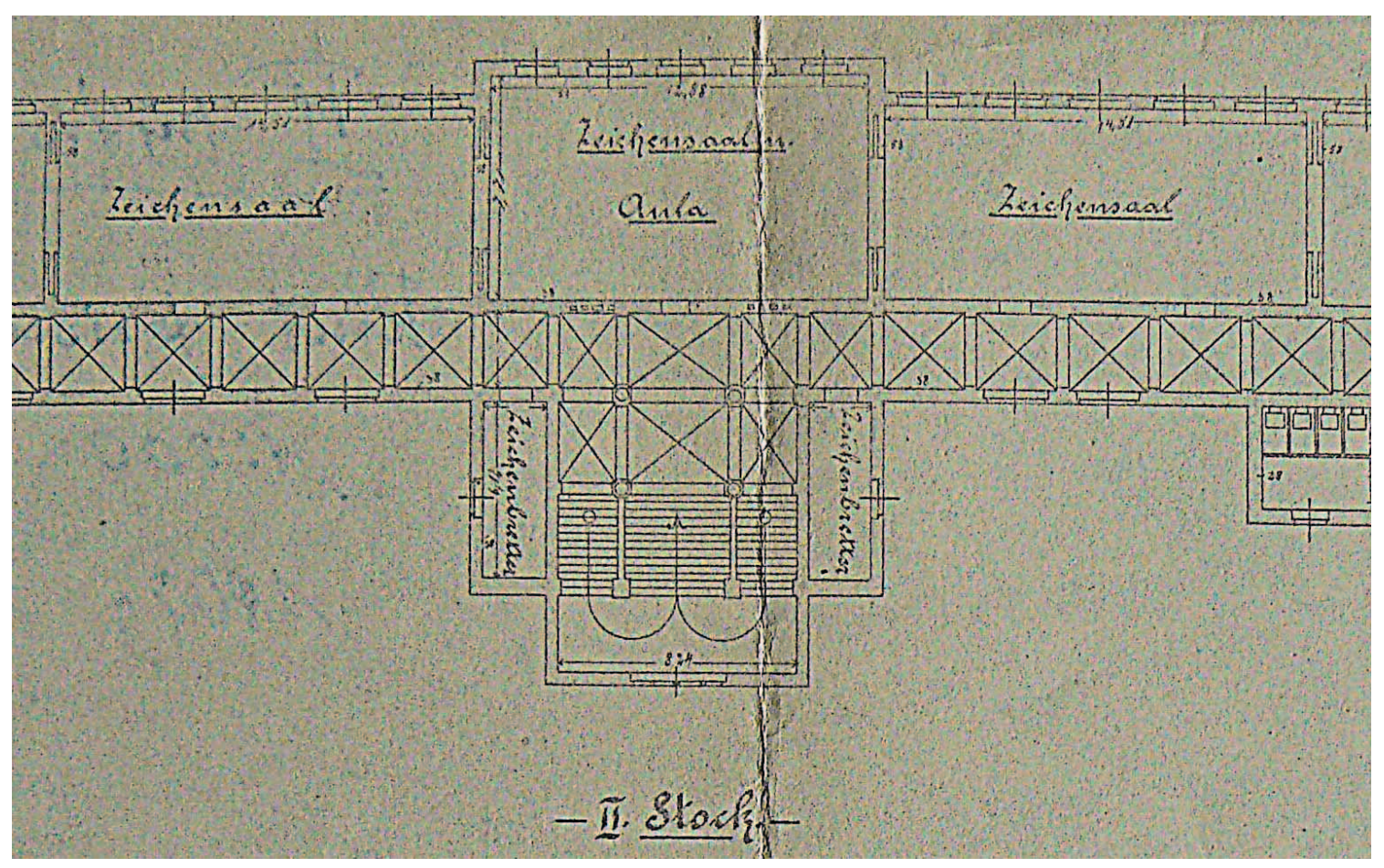

Il. 4. Szkoła Przemysłowa, II piętro, fragment, rzut poziomy 1:200, 1902 r., kopia; projekt w posiadaniu Kierownika Obiektu Dydaktycznego Collegium Maius UMK w Toruniu 


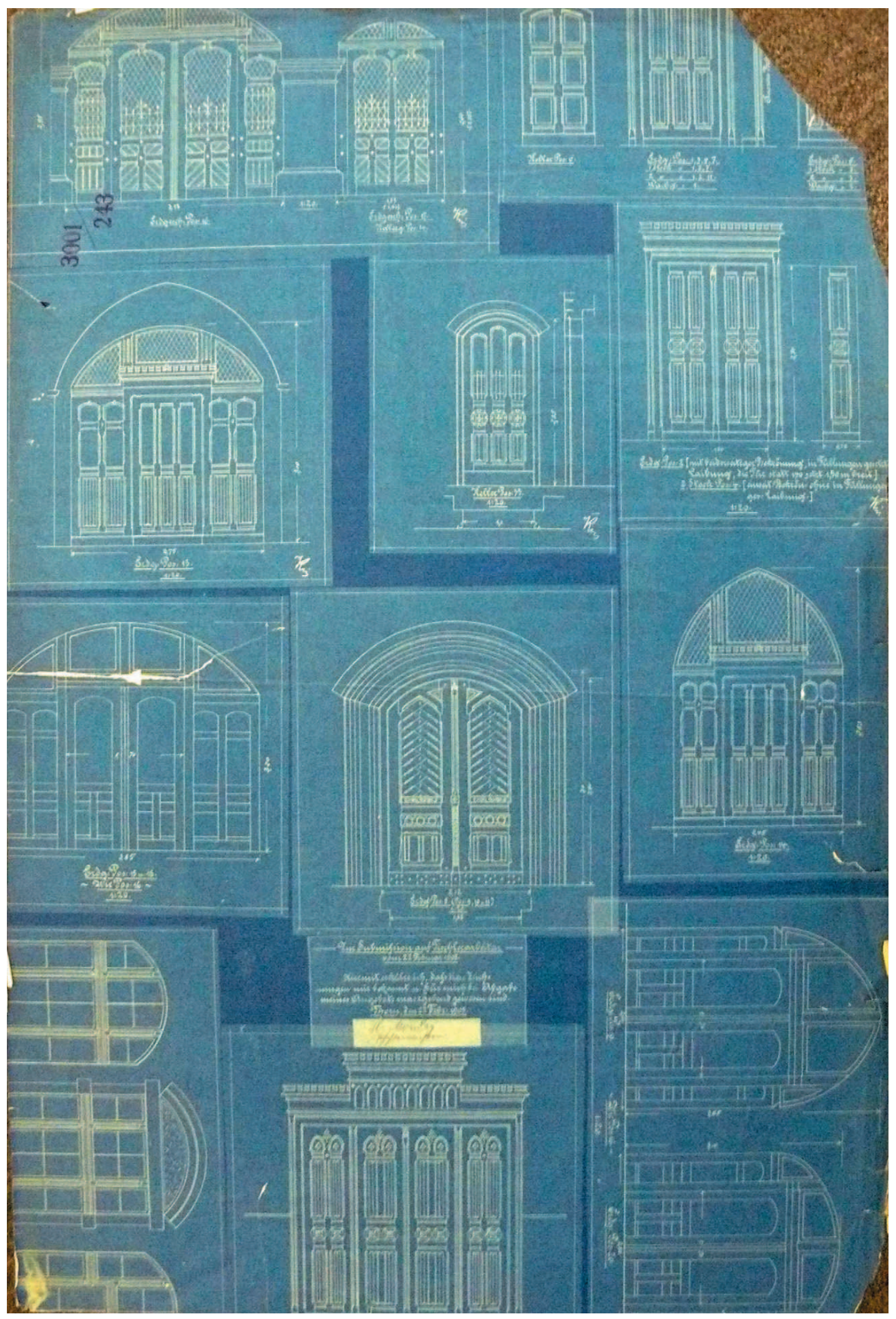

Il. 5. Projekt drzwi, APT, AmT, T 47, K. 33 


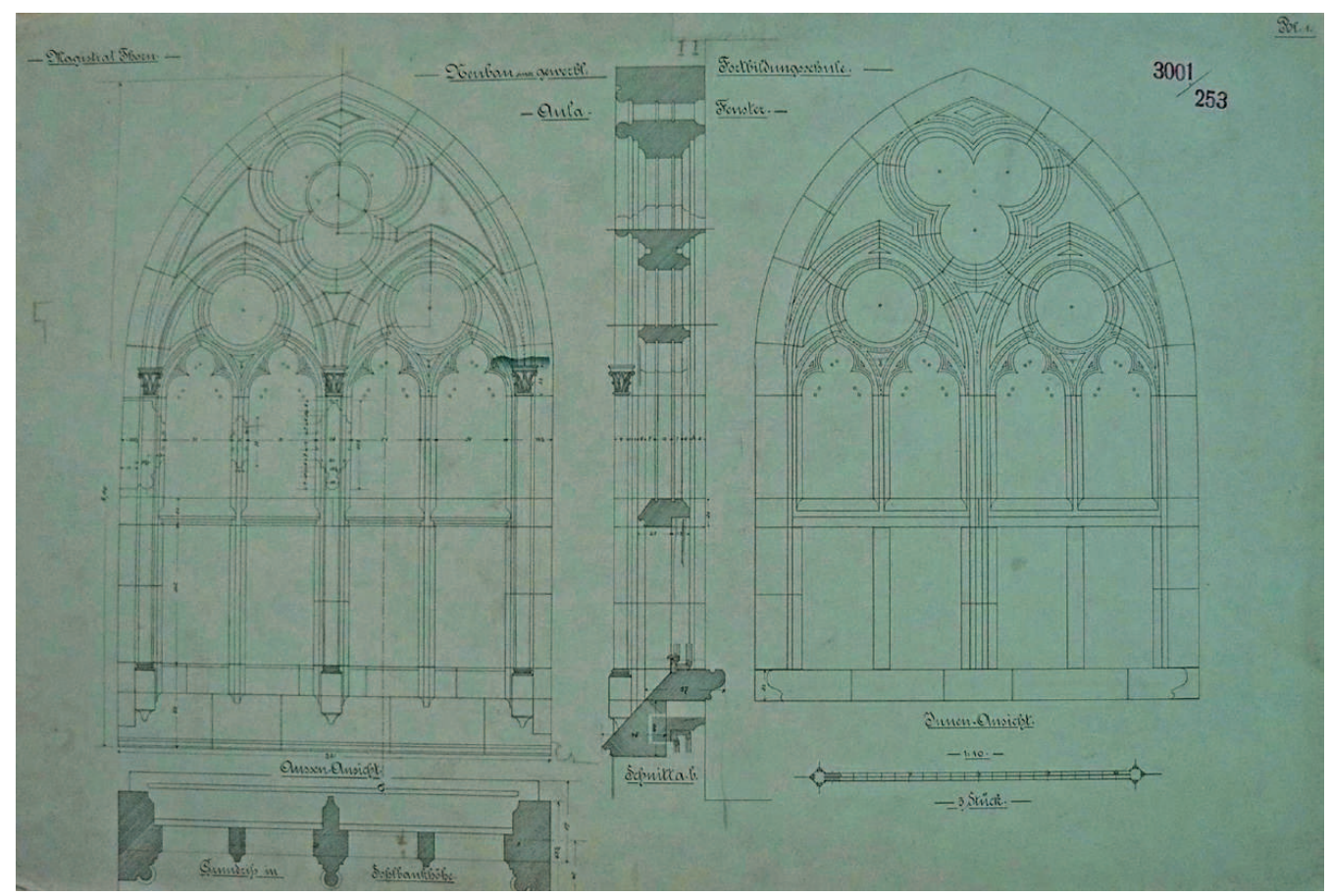

Il. 6. Projekt okien, APT, AmT, T 47, K. 58

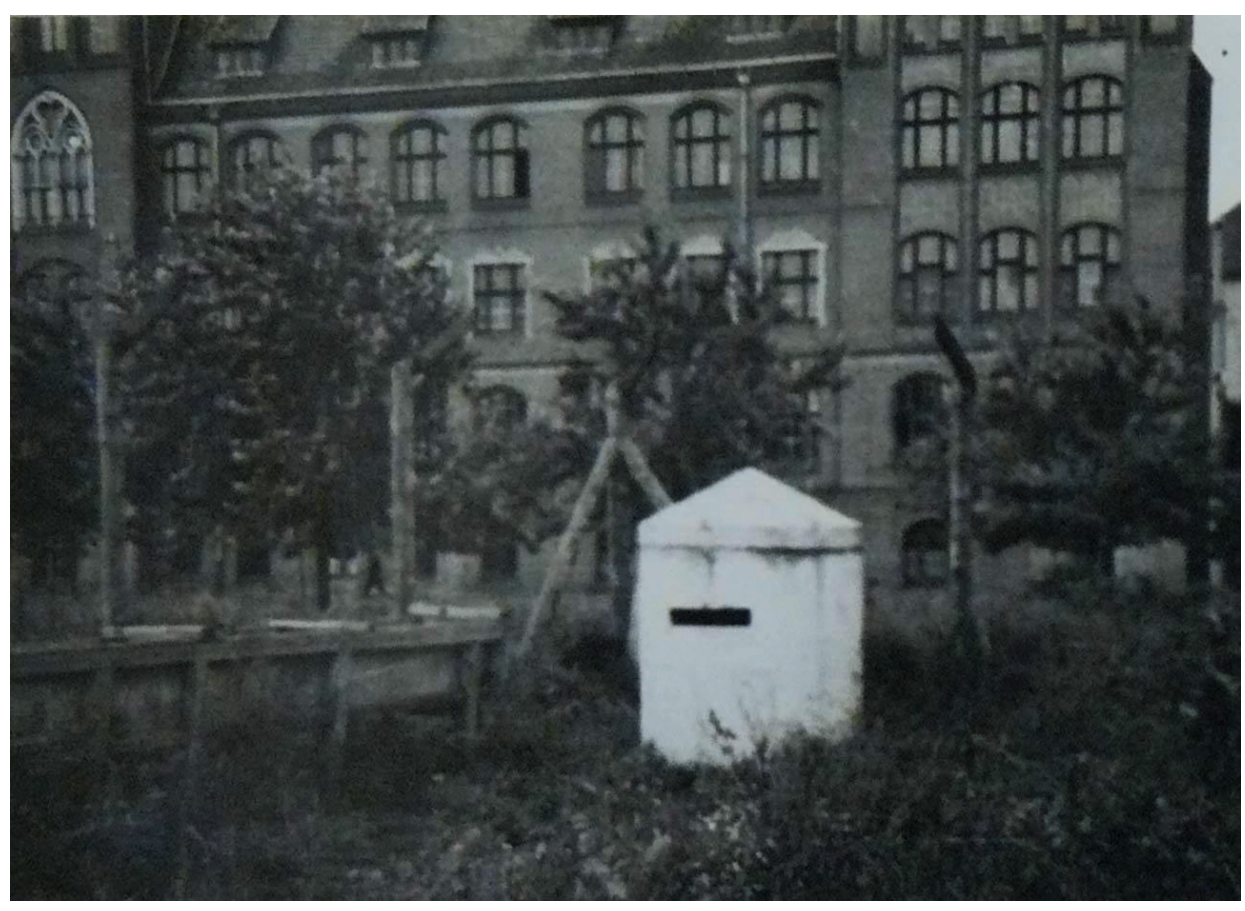

Il. 7. Widok z obozu przy ul. 700-lecia na siedzibę Państwowego Zarządu Policyjnego mieszczącego się przy ul. Fosa Staromiejska 3, 1945 r., APT, Archiwum Alojzego Czarneckiego, K. 34 (fragment) 
REKTOR I SENAT

U N I W ER S Y T E T U

MIKOŁAJA KOPERNIKA

ZAPRASZAJA NA UROCZYSTOŚĆ

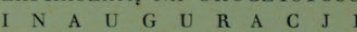

ROKU AKADEMICKIEGO $1947 / 48$

W DNIU 11 PAŹDZIERNIKA 1947 R.
PRZEBIEG UROCZYST OŚCI: GODZ. 10 - NABOŻENSTWO W KOŚCIELE N. M. P.

A I U

2. PRZEMÓWIENIEI I SPRAWOZDANIE J.M.REKTO-

RA PROF. DR LUDWIKA KOLANKOWSKIEGO

Z ROZWOJU UNIWERSYTETU W R. 1946.47

WYEAD PAOS. DR WE. NAWYSEOWSKEGO

W ZAKPESIE STANOWIENA I STOSOWIVIA

PRAWA

PROMOCJE DOKTORSKIE

5. IMMATRYKULACJA

Il. 8. Zaproszenie na inaugurację roku akademickiego 1947/1948, Wojewódzka Biblioteka Publiczna - Książnica Kopernikańska, Dział Zbiorów Specjalnych, sygn. LX/13

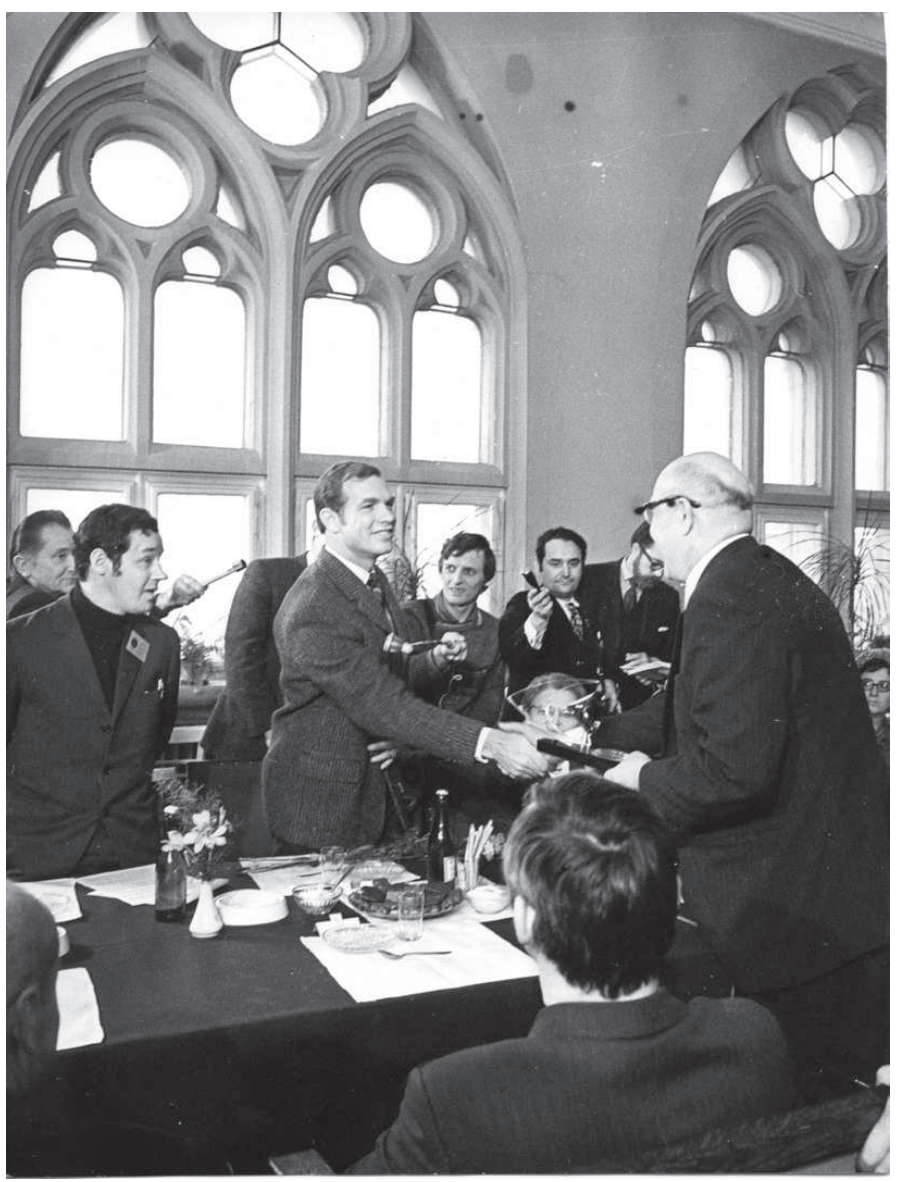

Il. 9. Wizyta astronomów amerykańskich w Toruniu, 22 stycznia 1972 r.; zdjęcie wykonane w dzisiejszej sali im. L. Kolankowskiego Collegium Maius UMK, A. UMK, sygn. 307D 


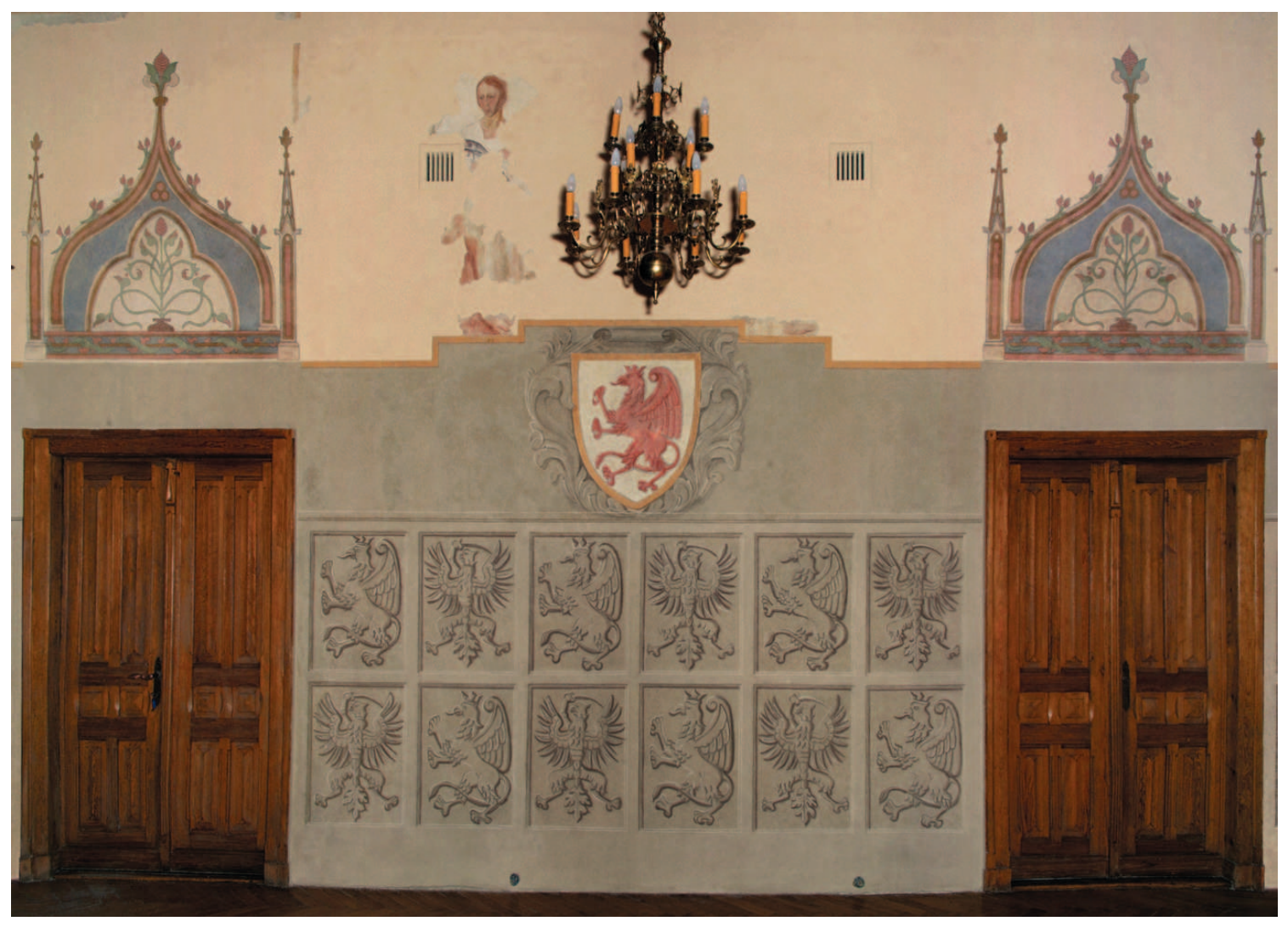

Il. 10. Sala im. L. Kolankowskiego Collegium Maius UMK, ściana południowa, stan po ukończeniu prac konserwatorskich, 2009 r. (fot. W. Grzesik) 


\section{Summary}

\section{History of NCU Collegium Maius Building in Toruń}

The present article is a part of a historical documentation of Ludwik Kolankowski hall in Nicolaus Copernicus University Collegium Maius in Toruń. Maintenance and restoration of the aforementioned building was performed by a team of conservators under a supervision of prof. Bogumiła Rouba in 2008.

Collegium Maius building of Nicolaus Copernicus University is located at 3 Fosa Staromiejska street in Torun. Originally the Industrial School was located there. After the World War I it became a seat of the Pomerania Provincial Office (till 1939). During the World War II the State Police Management Board, and since 1944 also the SS command centre were placed there. In November 1945 the building was transferred to a newly founded Nicolaus Copernicus University. Until a campus in Bielany was built, Collegium Maius housed: Vice Chancellor's office, NCU administration's offices, the Senate's meetings hall, Deans' Offices, lecture halls, and also studios of the Faculty of Fine Arts. Nowadays in Collegium Maius the NCU Faculty of Languages is located. 